\title{
Determination of Copper and Cadmium in Petroleum Produced Formation Water by Electrothermal Atomic Absorption Spectrometry after Cloud Point Extraction
}

\author{
Valdinei S. Souza, ${ }^{\circledR a}{ }^{a}$ Leonardo S. G. Teixeira, ${ }^{b}$ Queila O. Santos, $^{c}$ Ivaldo S. Gomes $^{d}$ and \\ Marcos A. Bezerra ${ }^{(1), d}$ \\ anstituto Federal de Educação, Ciência e Tecnologia Baiano, Rodovia Santa Inês (BR 420), \\ Ubaíra, Zona Rural, 45320-000 Santa Inês-BA, Brazil \\ ${ }^{b}$ Instituto de Química, Universidade Federal da Bahia, Campus Universitário de Ondina, \\ 40170-115 Salvador-BA, Brazil \\ 'Instituto Federal de Educação, Ciência e Tecnologia Baiano, Rodovia Itapetinga/Itororó, km 02, \\ Clerolândia, 45700-000 Itapetinga-BA, Brazil \\ ${ }^{d}$ Departamento de Ciências e Tecnologias, Universidade Estadual do Sudoeste da Bahia, \\ Rua José Moreira Sobrinho s/n, 45208-409 Jequié-BA, Brazil
}

\begin{abstract}
Cloud point extraction (CPE) in association with graphite furnace atomic absorption spectrometry (GFAAS) was proposed for preconcentration and quantification of trace amounts of copper and cadmium in samples of saline produced formation water from petroleum exploration. The procedure was based on the formation of hydrophobic complexes of the analytes with 1,5-diphenylthiocarbazone (dithizone) in a micellar media of the surfactant (1,1,3,3-tetramethyl butyl) phenyl-polyethylene glycol (Triton X-114). Constrained mixture design was performed for the optimization of the proportions of the three solutions employed in the CPE: Triton X-114, dithizone, and buffer solution. Under the recommended conditions, the CPE GF AAS procedure allowed to obtain enrichment factors of 18 and 11 times, limits of quantification of 0.030 and $0.12 \mu \mathrm{g} \mathrm{L}^{-1}$ and precision, expressed as relative standard deviation ( $\mathrm{RSD}, \mathrm{n}=8,2.0 \mu \mathrm{g} \mathrm{L}^{-1}$ ), of 1.1 and $4.3 \%$ for copper and cadmium, respectively. The CPE GF AAS method was applied to the determination of copper and cadmium in samples of saline produced formation water from petroleum exploration, and its accuracy was accessed by analyzing certified reference material CASS-5 (Nearshore Seawater Reference Material for Trace Metals) from National Research Council (Canada).
\end{abstract}

Keywords: produced-formation water, constrained mixture design, cloud-point extraction, cadmium, copper

\section{Introduction}

Petroleum produced-formation waters (PFW) is typically generated along with oil or effluents resulting from the separation processes in existing gathering and treatment stations in the oil production. ${ }^{1}$ The environmental hazards associated with the produced-formation water may vary depending on the composition of the water, the characteristics of the rocks in which it occurs and of its final disposal. It is a practice throughout the oil industry, physically separating water from fluids and then discard them directly into the ocean or injecting it back into the

*e-mail: mbezerra47@yahoo.com.br wells or other suitable geological formations, with or without further treatment. ${ }^{2}$ The PFW is a complex mixture constituting of the injection water, hydrocarbons residual, metals in the form of inorganic salts, radioactive materials and chemical residues added during the production and treatment process in the extraction.

Toxic metals can influence the biodegradation of organic substances by altering the activity or the microbial population. Various elements such as lead, cadmium, nickel, chromium, copper, and zinc have been studied demonstrating this action..$^{3-5}$ Among the metals of environmental interest, copper stands out for problems to the aquatic environment, since they exhibit the same toxicity, persistence, and bioaccumulation in the food 
chain. ${ }^{6}$ Cadmium is captured and retained by terrestrial and aquatic plants and can be concentrated in the liver and kidneys of animals that feed on these plants. ${ }^{4,7}$ The effects of these toxic metals on aquatic organisms include changes in growth, reproduction, and distribution of the population. ${ }^{8}$

In the final of the past century, there has been a breakthrough in the development of analytical instrumentation with the ability to determine concentrations of the analytes in trace amounts. ${ }^{9}$ Several equipments with high sensitivity and low detection limits have been developed; however, there are few analytical techniques that allow sample introduction without pretreatment. The analyzes in environmental chemistry are hampered because usually, the samples to be studied exhibit complex matrices that prevent or hinder the determination of the species of interest. ${ }^{10}$ Therefore, sample treatment is considered a crucial step in the chemical analysis process.

Cloud-point extraction (CPE) has been one of the most efficient techniques for separation and pre-concentration of metal ions and traces elements. ${ }^{11-14}$ The cloud point is a phenomenon in which an aqueous surfactant solution becomes cloudy by adding an appropriate substance or by changing some of its properties such as temperature or pressure. ${ }^{15}$ The use of the CPE has been described in various types of matrices and also coupled to different detection techniques for the determination of inorganic species among which are inductively coupled plasma optical emission spectrometry (ICP OES), ${ }^{2,16}$ flame atomic absorption spectrometry (F AAS), ${ }^{6,17}$ thermospray flame furnace atomic absorption spectrometry (TS-FF-AAS), ${ }^{18}$ spectrophotometry UV-Vis, ${ }^{19}$ and graphite furnace atomic absorption spectrometry (GF AAS). ${ }^{12}$

In the present paper, CPE, in association with GFAAS, is proposed for preconcentration and determination of copper and cadmium in samples of PFW. The procedure was based on the formation of hydrophobic complexes of the analytes with 1,5-diphenylthiocarbazone (dithizone) in a micellar media of the surfactant (1,1,3,3-tetramethyl butyl) phenyl-polyethylene glycol (Triton X-114). Constrained mixture design was performed for the optimization of the proportions of the three solutions employed in the CPE: Triton X-114, dithizone, and buffer solution.

\section{Experimental}

Instrumentation

Metals determination were made using a AAnalyst 400 graphite furnace atomic absorption spectrometer, equipped with a background corrector with deuterium arc lamp, graphite furnace (with integrated platform and covered with pyrolytic graphite) as an atomizer, hollow cathode lamps and an AS 800 autosampler (PerkinElmer, Norwalk, CT, USA). All measurements were performed at the highest sensitivity wavelength indicated by the equipment for each element: $228.80 \mathrm{~nm}(\mathrm{Cd})$ and $283.31 \mathrm{~nm}(\mathrm{Cu})$. High purity argon gas (99.99\%, Itaox, Brazil) was used for the purging and protection of the graphite furnaces. A centrifuge Quimis Q222T model (São Paulo, Brazil) with a capacity of sixteen tubes of $15 \mathrm{~mL}$ was used to accelerate the separation of the surfactant-rich phase from the aqueous phase. A system Elga (Purelab Classic) was used to obtain ultrapure water (conductivity of $18 \mathrm{M} \Omega \mathrm{cm}$ ).

\section{Reagents and solutions}

Chemicals used in this work were of analytical purity grade, and the solutions were prepared with ultrapure water. The stock solutions (1000 $\left.\mathrm{mg} \mathrm{L}^{-1}\right)$ of copper and cadmium were individually prepared from the dilution $1 \% \mathrm{HCl}\left(\mathrm{v} \mathrm{v}^{-1}\right)$ of the standard solution (Merck, Darmstadt, Germany). Dithizone (Sigma-Aldrich, Milwaukee, USA, purity > 98\%) solution was prepared in the concentration of $0.040 \%$ $\left(\mathrm{m} \mathrm{v}^{-1}\right)$ from dissolving a mass of $0.0040 \mathrm{~g}$ of the reagent to a volume of $10.0 \mathrm{~mL}$ with $95 \%$ hydrated ethyl alcohol (Exodo Científica, São Paulo, Brazil). A solution of $10 \%\left(\mathrm{v} \mathrm{v}^{-1}\right)$ Triton X-114 (Sigma-Aldrich, Milwaukee, USA) surfactant was prepared by diluting $10.0 \mathrm{~mL}$ of the concentrated surfactant to a final volume of $100.0 \mathrm{~mL}$ with ultrapure water and solubilized by ultrasound energy. A $1.0 \%\left(\mathrm{v} \mathrm{v}^{-1}\right)$ $\mathrm{HNO}_{3}$ solution for decrease the viscosity of the surfactant rich phase was prepared by diluting $1.0 \mathrm{~mL}$ of $\mathrm{HNO}_{3}$ in ethanol. Solutions of sodium chloride at concentrations between 1 and $8 \%\left(\mathrm{~m} \mathrm{v}^{-1}\right)$ were prepared by dissolving an adequate amount of $\mathrm{NaCl}$ in deionized water to obtain the desired concentrations. Buffer solutions $\left(0.1 \mathrm{~mol} \mathrm{~L}^{-1}\right)$ were prepared for the $\mathrm{pH}$ values 4.0, 5.0, 6.0, 7.0, 9.0 and 10.0 using acetic acid/sodium acetate, tris-(hydroxymethyl)aminomethane/HCl or boric acid/sodium borate (SigmaAldrich, Milwaukee, USA). Palladium nitrate solution and magnesium nitrate (1000 $\mathrm{mg} \mathrm{L}^{-1}$ ) (Merck, Kenilworth, USA) were used as chemical modifiers to stabilize the analytes in the pyrolysis step, allowing a higher temperature to be used. The proportion of $\mathrm{Pd} / \mathrm{Mg}$ adopted was 5:3 $\left(\mathrm{v} \mathrm{v}^{-1}\right)$.

\section{Sample collection and treatment}

The produced-formation water samples were collected from offshore drilling petroleum platforms using polyethylene bottles pre-decontaminated with a $5 \%\left(\mathrm{v} \mathrm{v}^{-1}\right)$ $\mathrm{HNO}_{3}$ solution. The samples were filtered through membranes of pore size $0.45 \mu \mathrm{m}$ with the aid of a 
filtration system that operates under vacuum to remove the suspended particulate matter. These samples were subsequently acidified to $\mathrm{pH}<2$ with nitric acid and cooled in a refrigerator to ensure the stability of trace elements. Sample salinities were determinate by titration with $\mathrm{AgNO}_{3}$. Samples have presented salinities in the range of 1.5 to $7.5 \%$.

\section{Optimization of the method}

The variables volume of the surfactant Triton X-114 $10 \%\left(\mathrm{v} \mathrm{v}^{-1}\right)$, volume and concentration of the complexing agent (dithizone), $\mathrm{pH}$ value, volume of buffer solution, volume of $1 \% \mathrm{NaCl}$ solution, and volume of the diluent $(1 \%$ $\mathrm{HNO}_{3}$ solution) were studied in the optimization process. A constrained mixture design was used for multivariate optimization of the proportions of the mixture components that were added to $10-\mathrm{mL}$ of the sample: solution of surfactant $10 \%\left(\mathrm{v} \mathrm{v}^{-1}\right)$ Triton X-114, buffer solution and $0.04 \%\left(\mathrm{~m} \mathrm{v}^{-1}\right)$ dithizone solution.

Aiming to choose the best conditions for $\mathrm{Cu}$ and $\mathrm{Cd}$ complexation by dithizone, $\mathrm{pH}$ values were evaluated between 4.0 and 10.0. In the optimization of the surfactant volume was studied volumes in the range of 50 to $350 \mu \mathrm{L}$. The volume of solution complexing reagent dithizone was studied in the range between 50 and $350 \mu \mathrm{L}$ considering fixed values of the other variables, except those determined by previous studies of $\mathrm{pH}$ and volume of surfactant. It was also studied the optimal value of diluents micellar phase and the influence of the concentration of electrolyte, by determining the optimum amount of $1 \% \mathrm{NaCl}$ in the range $0-175 \mu \mathrm{L}$.

\section{Optimization of the GF AAS heating program}

As the surfactant-rich phase has very different characteristics from an aqueous solution usually analyzed by GF AAS, the pyrolysis and atomization temperatures were studied to obtain the best performance. The modifier $\mathrm{Pd} / \mathrm{Mg}$ was used in the analysis, considering that cadmium is an element of high volatility.

\section{Cloud point extraction procedure}

The sample was put in a polyethylene centrifuge tube, buffered with a solution $15 \mathrm{mmol} \mathrm{L}^{-1}$ of acetic acid/sodium acetate (pH 5.0) for the extraction of copper and $20 \mathrm{mmol} \mathrm{L}^{-1}$ solutions of boric acid/sodium borate ( $\mathrm{pH}$ 9.0) for extraction of cadmium. A volume of $100 \mu \mathrm{L}$ of the dithizone solution and a volume of $150 \mu \mathrm{L}$ of the Triton X-114 10\% $\left(\mathrm{v} \mathrm{v}^{-1}\right)$ solution were added to $10 \mathrm{~mL}$ of the sample. A $10 \%\left(\mathrm{~m} \mathrm{v}^{-1}\right)$ $\mathrm{NaCl}$ solution was also added to favor the separation of surfactant-rich phase from the aqueous phase. To allow the phases separation, the system was centrifuged for $8 \mathrm{~min}$ and then subjected to an ice bath for $10 \mathrm{~min}$. The aqueous phase was discarded by inversion of the tube. The micellar phase was diluted with $1 \%\left(\mathrm{v} \mathrm{v}^{-1}\right) \mathrm{HNO}_{3}$ ethanolic solution and analyzed by atomic absorption spectrometer graphite furnace for the determination of metals.

\section{Results and Discussion}

\section{Optimization of the heating temperature}

The study of the pyrolysis and atomization temperatures was performed in the micellar phase obtained after application of the CPE for the determination of copper and cadmium in PFW samples (Figure 1). For $\mathrm{Cu}$ and $\mathrm{Cd}$, $\mathrm{Pd} / \mathrm{Mg}$ modifier allows pyrolysis temperatures of 1200 and $500^{\circ} \mathrm{C}$ and atomization temperatures of 2400 and $2200^{\circ} \mathrm{C}$, respectively. The heating programming established is presented in Table 1.

\section{Optimization of the method}

The $\mathrm{pH}$ is a variable that has a significant effect on the extraction in the CPE of metallic analytes. In the case of metals, the extraction is done after the formation of chelates, whose complexation reaction is more effective at a certain $\mathrm{pH}$ range. The process is dependent on several factors, such as the distribution of the chelating between the aqueous and micellar phases, acid dissociation of the complexing agent, the formation of the hydrophobic chelate, and its

Table 1. Heating programming for determining copper and cadmium in the micellar phase obtained after cloud point extraction

\begin{tabular}{lccccc}
\hline Step & Temperature for $\mathrm{Cu} /{ }^{\circ} \mathrm{C}$ & Temperature for $\mathrm{Cd} /{ }^{\circ} \mathrm{C}$ & Ramp $/ \mathrm{s}$ & Hold $/ \mathrm{s}$ & Air flow rate $/(\mathrm{mL} \mathrm{min}-1)$ \\
\hline Drying 1 & 100 & 100 & 5 & 20 & 250 \\
Drying 2 & 140 & 140 & 15 & 15 & 250 \\
Pyrolysis & 1200 & 500 & 10 & 20 & 250 \\
Atomization & 2400 & 2200 & 0 & 5 & 0 \\
Clean & 2600 & 2600 & 1 & 5 & 250 \\
\hline
\end{tabular}


(a)

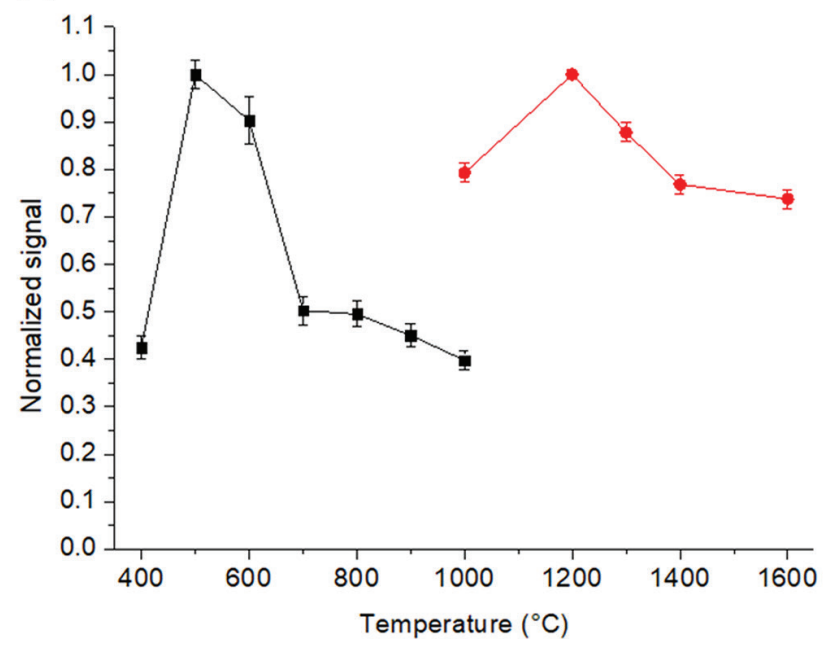

(b)

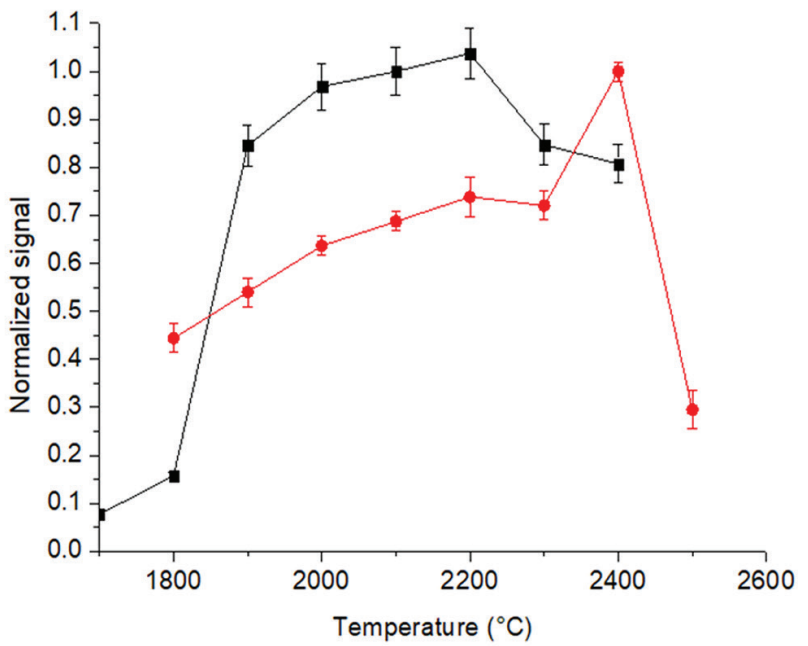

Figure 1. (a) Pyrolysis curves in the surfactant rich phase with atomization temperature at 2200 and $2100{ }^{\circ} \mathrm{C}$ for $\mathrm{Cu}(\mathbf{})$ and $\mathrm{Cd}$ ( $\mathbf{}$ ), respectively. (b) Atomization curves in the surfactant rich phase with pyrolysis temperature at 1200 and $500{ }^{\circ} \mathrm{C} \mathrm{for} \mathrm{Cu}(\mathbf{O})$ and $\mathrm{Cd}(\mathbf{\square})$, respectively.

distribution in the micellar phase. The acid dissociation of the chelating agent is directed as a function of $\mathrm{pH}$, and this will determine whether the metal will be complexed or not.

The effect of $\mathrm{pH}$ on the copper and cadmium extraction with dithizone was evaluated. The study of this variable was carried out between $\mathrm{pH}$ values 4.0 and 10.0, obtaining the values of absorbance versus $\mathrm{pH}$ (Figure 2a). The values of the other variables were set at $20 \mathrm{mmol} \mathrm{L}^{-1}$ for the buffer solution concentration, $0.020 \mathrm{mmol} \mathrm{L}^{-1}$ for the dithizone concentration, $0.2 \%\left(\mathrm{v} \mathrm{v}^{-1}\right)$ for the Triton $\mathrm{X}-114$ solution concentration, $50 \mu \mathrm{L}$ of $\mathrm{NaCl}\left(10 \% \mathrm{~m} \mathrm{v}^{-1}\right)$ for a sample final volume of $10.0 \mathrm{~mL}$. Copper and cadmium have better extraction levels at different $\mathrm{pH}$ ranges. The best absorbance signal for copper extraction occurred at $\mathrm{pH} 5.0$, while for cadmium, the best $\mathrm{pH}$ was between 8.0 and 10.0. Even the cadmium having a broader range of optimum value, the intermediate value 9.0 was chosen because it is more robust and does not affect the absorbance too much if there are variations to its surroundings. Aiming to study the other variables, the optimum $\mathrm{pH}$ values of 5.0 and 9.0 were set for copper and cadmium, respectively.

The study of the concentration of buffer solution on the extraction of the metal has the objective of discovering the concentration capable of buffering the sample without causing a decrease in the analytical signal. For copper, for example, the decrease in response after $20 \mathrm{mmol} \mathrm{L}^{-1}$ concentration was noted (Figure $2 \mathrm{~b}$ ), probably due to reactions competition of the acetate and the dithizone with the analyte. It is verified that concentrations between 15 and $20 \mathrm{mmol} \mathrm{L}^{-1}$ are the optimal values for $\mathrm{Cu}$ and $\mathrm{Cd}$ extraction.

The enrichment factor of the analyte depends on the ratio between the volume of the surfactant-rich phase and the bulk aqueous phase. A higher volume of the rich phase gives lower enrichment factors and vice versa. On the other hand, a very small volume of surfactant may not be sufficient to extract all the metal chelate present in the solution. To study this dependence, the concentration of the surfactant solution added was in the range of 0.05 to $0.35 \%\left(\mathrm{v} \mathrm{v}^{-1}\right)$. The optimum Triton X-114 concentration for copper and cadmium was $0.15 \%\left(\mathrm{v} \mathrm{v}^{-1}\right)$, as can be seen in Figure 2c, and was adopted for further experiments.

Separation of metallic analytes by CPE demand to form hydrophobic chelates, and they can be extracted by the micellar phase. A hydrophobic neutral chelate is a necessary condition for extraction when non-ionic surfactants are used. The complexing reagent 1,5-diphenylthiocarbazone (dithizone) was used to form stable and neutral complexes with both analytes, copper and cadmium. Figure $2 \mathrm{~d}$ shows the variation of absorbance intensities along with the concentration variation of dithizone.

A concentration of $0.025 \mathrm{mmol} \mathrm{L}^{-1}$ was chosen for both copper and cadmium determination. It is possible to realize that the concentration of the complexing solution considerably affects the extraction of both metals. The excess of complexing solution does not favor extraction due to the salting in effect caused by the solvent (ethyl alcohol) used in the solubilization of the dithizone reagent. This behavior can be noted by reducing the absorbance value when increasing the concentration of the complexing solution in both metals since the increase in dithizone concentration was achieved by increasing the volume of the dithizone solution in ethanol $0.040 \%\left(\mathrm{v} \mathrm{v}^{-1}\right)$.

The surfactant phase obtained after extraction at the cloud point has a high viscosity, which makes it difficult to inject in the graphite tube, and it is necessary to dilute 
(a)

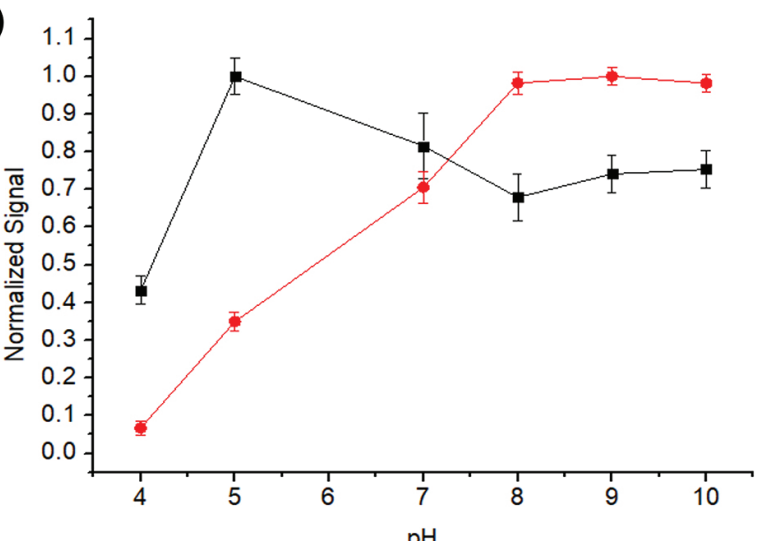

(c)

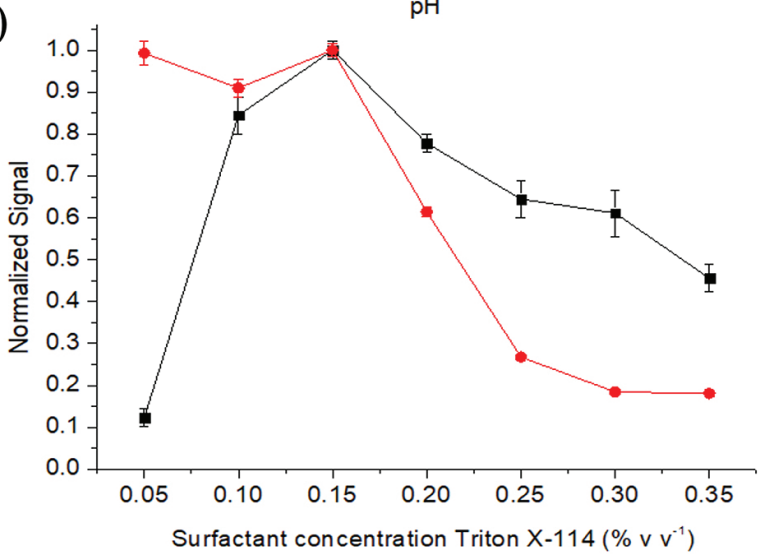

(b)

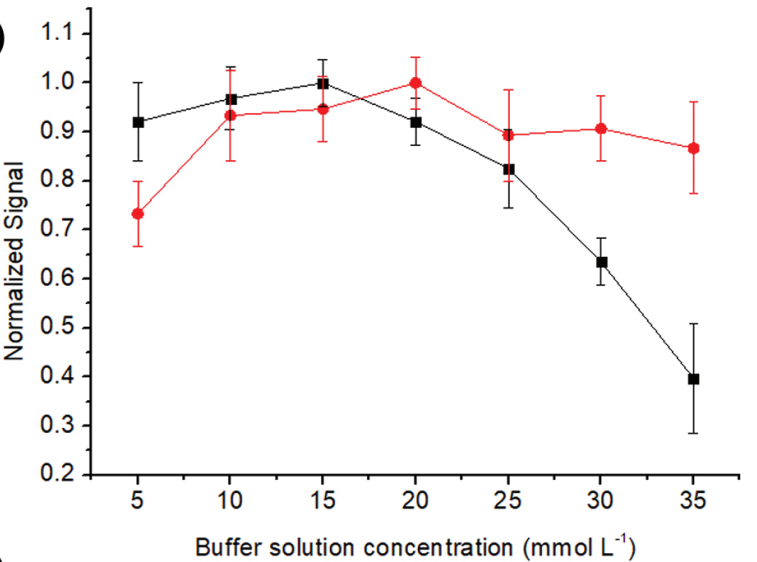

(d)

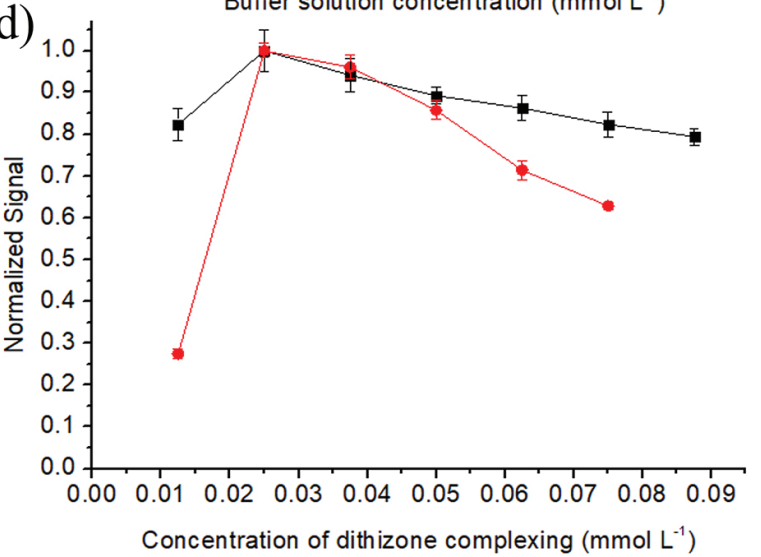

Figure 2. Studies for optimization of the CPE for copper ( $\mathbf{\square}$ ) and cadmium (-): (a) effect of pH using $2.0 \mathrm{~mL}$ of buffer solution, $100 \mu \mathrm{L}$ of dithizone complexing, $200 \mu \mathrm{L}$ of Triton X-114 surfactant and $50 \mu \mathrm{L}$ of $10 \%\left(\mathrm{~m} \mathrm{v}^{-1}\right) \mathrm{NaCl}$ solution; (b) effect of the concentration of the buffer solution using pH 5.0 and 9.0 for $\mathrm{Cu}$ and $\mathrm{Cd}$, respectively, $100 \mu \mathrm{L}$ of dithizone complexing, $200 \mu \mathrm{L}$ of Triton surfactant X-114 and $50 \mu \mathrm{L} \mathrm{of} 10 \%$ (m v $\left.\mathrm{v}^{-1}\right) \mathrm{NaCl}$ solution; (c) study of Triton X-114 surfactant concentration using $15 \mathrm{mmol} \mathrm{L}^{-1}$ acetate buffer at $\mathrm{pH} 5.0,20 \mathrm{mmol} \mathrm{L}^{-1}$ borate buffer at $\mathrm{pH} 9.0,100 \mu \mathrm{L}$ of complex dithizone $\left(0.040 \%, \mathrm{~m} \mathrm{~m}^{-1}\right)$ and $50 \mu \mathrm{L}$ of $10 \%\left(\mathrm{~m} \mathrm{v}^{-1}\right) \mathrm{NaCl}$ solution and (d) effect of the concentration of complexing solution using $15 \mathrm{mmol} \mathrm{L}^{-1}$ acetate buffer solution pH $5.0(\mathrm{Cu}), 20 \mathrm{mmol} \mathrm{L}^{-1}$ borate buffer solution $\mathrm{pH} 9.0(\mathrm{Cd}), 0.15 \%\left(\mathrm{v} \mathrm{v}^{-1}\right)$ Triton X-114 surfactant and $50 \mu \mathrm{L} 10 \%\left(\mathrm{~m} \mathrm{v}^{-1}\right) \mathrm{NaCl}$ solution.

it. The best responses were obtained for values lower than $50 \mu \mathrm{L}$ and, when no volume of diluent was added, the error caused was very large. Therefore, a volume of $50 \mu \mathrm{L}$ of the $\mathrm{HNO}_{3}$ ethanolic solution was chosen for dilution of the surfactant phase.

\section{Multivariate optimization}

Aiming to increase the extraction performance, a constrained mixture design was applied to optimize the proportions of the solutions that promote the cloud-point extraction of the analytes. The applied constraints delimited the experimental region avoiding undesirable experimental conditions. Table 2 presents the established constraints for each variable, and Table 3 presents the experimental matrix and obtained responses (absorbances for $\mathrm{Cu}$ and $\mathrm{Cd}$ ).

From the data of Table 3, mathematical functions (linear, quadratic, and special cubic) were fitted to describe the behavior of the data and to allow the location of the optimal experimental conditions. The linear models for the responses of both extracted metals leaving residuals (the difference between the value found experimentally and that predicted by the mathematical function) were very large and therefore present a low predictive capacity.

For copper data, the quadratic and special cubic models were also fitted. These two models adequately described the experimental region. However, because the quadratic model is simpler, it was chosen to optimize copper extraction (equation 1):

$\mathrm{y}_{\mathrm{Cu}}=-0.0710 \mathrm{x}_{1}+0.0202 \mathrm{x}_{2}+0.00868 \mathrm{x}_{3}+0.133 \mathrm{x}_{1} \mathrm{x}_{2}+$

$0.169 \mathrm{x}_{1} \mathrm{x}_{3}+0.0173 \mathrm{x}_{2} \mathrm{x}_{3}$

where $\mathrm{y}_{\mathrm{Cu}}$ is the predicted response, $\mathrm{x}_{1}$ is the proportion of the surfactant solution, $x_{2}$ is the proportion of the buffer solution, and $\mathrm{x}_{3}$ is the proportion of the complexing solution. Figure 3 a shows the response surface described by this quadratic model. This surface has a maximum point as a critical point. The coordinates of this point (indicated by the black arrow in Figure $3 \mathrm{a}$ ) are the proportions of the components that generate the highest response (absorbance) for the studied system. The optimum volumes found for 
Table 2. Low and high constraints for mixture design

\begin{tabular}{lccc}
\hline Mixture variable & Symbol & $\begin{array}{c}\text { Low } \\
\text { constraint } \\
(-1)\end{array}$ & $\begin{array}{c}\text { High } \\
\text { constraint } \\
(+1)\end{array}$ \\
\hline Surfactant volume $/ \mu \mathrm{L}$ & $\mathrm{SV}$ & 50 & 350 \\
Buffer volume $/ \mu \mathrm{L}$ & $\mathrm{BV}$ & 1800 & 2400 \\
Complexing volume $/ \mu \mathrm{L}$ & $\mathrm{CV}$ & 50 & 350 \\
\hline
\end{tabular}

copper extraction were $155 \mu \mathrm{L}(6.2 \%)$ of the surfactant solution, $2140 \mu \mathrm{L}(85.6 \%)$ of the acetate buffer solution, and $205 \mu \mathrm{L}$ (8.2\%) of the complexing solution.

For the cadmium data, only the special cubic model described the data behavior. Therefore, it was chosen to optimize the extraction of cadmium (equation 2):

$\mathrm{y}_{\mathrm{Cd}}=-0.0950 \mathrm{x}_{1}+0.033 \mathrm{x}_{2}-0.252 \mathrm{x}_{3}+0.336 \mathrm{x}_{1} \mathrm{x}_{2}+$

$1.132 \mathrm{x}_{1} \mathrm{x}_{3}+1.5 \mathrm{x}_{2} \mathrm{x}_{3}-2.176 \mathrm{x}_{1} \mathrm{x}_{2} \mathrm{x}_{3}$

where $y_{C d}$ is the predicted response, $x_{1}$ is the proportion of the surfactant solution, $x_{2}$ is the proportion of the buffer solution, and $x_{3}$ is the proportion of the complexing solution. Figure $3 \mathrm{~b}$ shows the response surface described by the cubic model. This surface has a cell point as a critical point. The coordinates of this point cannot be taken with the optimal proportions of the components since the cell point is only an inflection point between the regions of greatest and lowest surface response. As the intention is to maximize the response, the optimal condition (point indicated by black arrow in Figure 3b) was found by visual inspection and the recommended volumes found for the extraction of cadmium were $50 \mu \mathrm{L}$ (2\%) of the surfactant solution, $2100 \mu \mathrm{L}$ ( $84 \%$ ) of the acetate buffer solution and $350 \mu \mathrm{L}(14 \%)$ of the complexing solution.

\section{Studies of interferences}

The influence of some metal ions that form complexes with dithizone was investigated to identify possible interferents of the CPE method. The studied metal ions were $\mathrm{Ca}^{2+}, \mathrm{Mg}^{2+}, \mathrm{Co}^{2+}, \mathrm{Pb}^{2+}, \mathrm{Mn}^{2+}$ and $\mathrm{Zn}^{2+}$. The atomic absorption spectrometry is a very selective technique and, in general, does not suffer appreciable influence due to the presence of other metals than the one of interest. However, metals complexes with the dithizone and can compete with the complexation of the metal of interest and decrease the extraction efficiency. The tests were performed in the presence of $10 \mu \mathrm{g} \mathrm{L}-1$ of the analytes.

An interference was considered when the signal in the presence of the potential interfering ion caused a

Table 3. Experimental matrix and responses used for the optimization of the proportions of the solutions used in the CPE

\begin{tabular}{|c|c|c|c|c|c|}
\hline \multirow{2}{*}{ Experiment } & \multicolumn{3}{|c|}{ Variables } & \multicolumn{2}{|c|}{ Analytical signal $^{\mathrm{a}}$} \\
\hline & SV & $\mathrm{BV}^{\mathrm{b}}$ & $\mathrm{CV}$ & $\mathrm{Cu}$ & $\mathrm{Cd}$ \\
\hline \multirow{2}{*}{1} & \multirow{2}{*}{50} & \multirow{2}{*}{2400} & \multirow{2}{*}{50} & 0.072 & 0.031 \\
\hline & & & & 0.081 & 0.027 \\
\hline \multirow{2}{*}{2} & \multirow{2}{*}{350} & \multirow{2}{*}{2100} & \multirow{2}{*}{50} & 0.040 & 0.067 \\
\hline & & & & 0.028 & 0.052 \\
\hline \multirow{2}{*}{3} & \multirow{2}{*}{50} & \multirow{2}{*}{2100} & \multirow{2}{*}{350} & 0.068 & 0.270 \\
\hline & & & & 0.076 & 0.232 \\
\hline \multirow{2}{*}{4} & \multirow{2}{*}{350} & \multirow{2}{*}{1800} & \multirow{2}{*}{350} & 0.048 & 0.112 \\
\hline & & & & 0.048 & 0.099 \\
\hline \multirow{2}{*}{5} & \multirow{2}{*}{50} & \multirow{2}{*}{2250} & \multirow{2}{*}{200} & 0.08 & 0.273 \\
\hline & & & & 0.102 & 0.250 \\
\hline \multirow{2}{*}{6} & \multirow{2}{*}{350} & \multirow{2}{*}{1950} & \multirow{2}{*}{200} & 0.041 & 0.098 \\
\hline & & & & 0.032 & 0.111 \\
\hline \multirow{2}{*}{7} & \multirow{2}{*}{200} & \multirow{2}{*}{2250} & \multirow{2}{*}{50} & 0.088 & 0.058 \\
\hline & & & & 0.096 & 0.065 \\
\hline \multirow{2}{*}{8} & \multirow{2}{*}{200} & \multirow{2}{*}{1950} & \multirow{2}{*}{350} & 0.101 & 0.153 \\
\hline & & & & 0.084 & 0.165 \\
\hline \multirow{2}{*}{9} & & & & 0.088 & 0.155 \\
\hline & 200 & 2100 & 200 & 0.101 & 0.137 \\
\hline
\end{tabular}

${ }^{a}$ Measurements made in duplicate; buffer acetate ( $\mathrm{pH}$ 5.0) for $\mathrm{Cu}$ and buffer borate ( $\mathrm{pH}$ 9.0) for $\mathrm{Cd}$. SV: surfactant volume; BV: buffer volume; CV: complexing volume. 

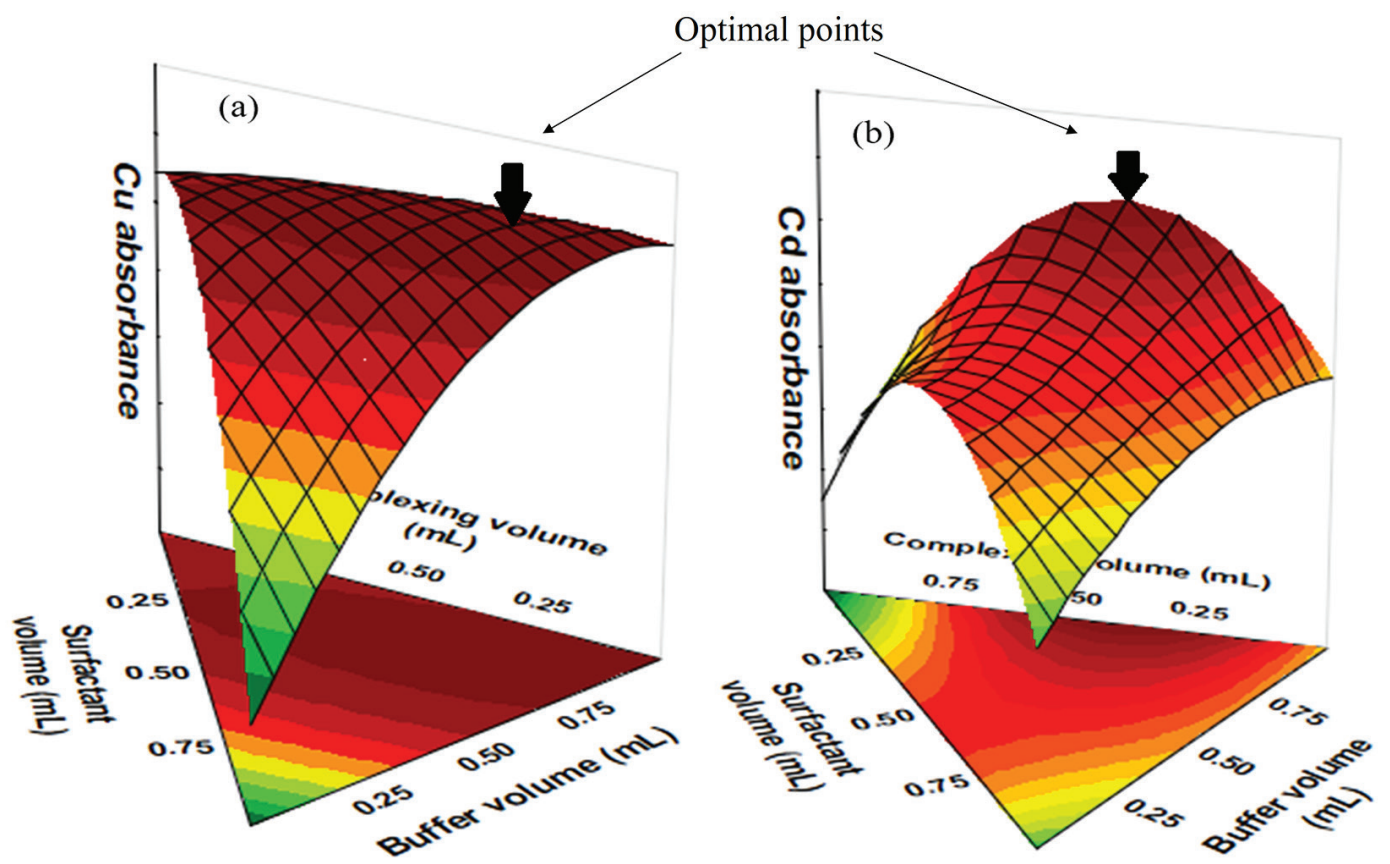

Figure 3. Response surfaces obtained by (a) quadratic model to the data of copper and (b) special cubic model to the data of cadmium.

change of $10 \%$ in the analytical signal, compared with the signals of $\mathrm{Cu}$ and $\mathrm{Cd}$ determination in the absence of interfering metals. For $\mathrm{Ca}$ and $\mathrm{Mg}$, concentrations greater than $200 \mu \mathrm{g} \mathrm{mL}^{-1}$ affected the signal magnitude. For the other tested species, no interference was observed until concentrations of $300 \mu \mathrm{g} \mathrm{mL} \mathrm{m}^{-1}$.

\section{Analytical characteristics}

After established the conditions for extraction of copper and cadmium from saline samples using the $\mathrm{CPE}$, the analytical characteristics of the method were accessed. Enrichment factors were calculated by the ratio of the angular coefficients of the curve obtained by the preconcentration process and the curve obtained by direct aspiration of the standard solutions (without preconcentration). Linearity for the determination of each element was evaluated, accessing their determination coefficients $\left(\mathrm{R}^{2}\right)$. Limits of detection (LOD) and limits of quantification (LOQ) were calculated based on the standard deviation (s) of ten measures of the blank solution, according to the following expressions: $\mathrm{LOD}=3 \mathrm{~s} / \mathrm{m}$ and $\mathrm{LOQ}=10 \mathrm{~s} / \mathrm{m}$, where $\mathrm{m}$ is the slope of the analytical curve. Precision was investigated in the form of repeatability using ten measurements for each element at $2.0 \mu \mathrm{g} \mathrm{L}{ }^{-1}$ and expressed as relative standard deviation (RSD, in percentage). Values found for these and other analytical characteristics are presented in Table 4.

The accuracy of the proposed method was evaluated by analysis of the certified reference material
Table 4. Analytical characteristics of the developed method based on cloud-point extraction of analytes and determination by GF AAS

\begin{tabular}{lcc}
\hline \multirow{2}{*}{ Analytical characteristics } & \multicolumn{2}{c}{ Analytes } \\
\cline { 2 - 3 } & $\mathrm{Cu}$ & $\mathrm{Cd}$ \\
\hline Worked concentration range / $\left(\mu \mathrm{g} \mathrm{L}^{-1}\right)$ & $0.030-5.0$ & $0.12-5.0$ \\
Linearity $\left(\mathrm{R}^{2}\right)$ & 0.9990 & 0.9860 \\
Sensitivity / $\left({\left.\mathrm{L} \mu \mathrm{g}^{-1}\right)}^{\text {Limit of detection / }\left(\mu \mathrm{g} \mathrm{L}^{-1}\right)}\right.$ & 0.201 & 0.231 \\
Limit of quantification / $\left(\mu \mathrm{g} \mathrm{L}^{-1}\right)$ & 0.010 & 0.041 \\
Enrichment factor & 0.030 & 0.12 \\
Repeatability $\left(\mathrm{RSD}, 20 \mu \mathrm{g} \mathrm{L}^{-1}\right) / \%$ & 18.0 & 10.6 \\
\hline
\end{tabular}

CASS5 (Nearshore Seawater Reference Material for Trace Metals) from National Research Council (Canada). For copper, found values by application of the CPE GF AAS methodology $\left(0.395 \pm 0.035 \mu \mathrm{g} \mathrm{L}^{-1}\right)$ were not statistically different from the certified value $\left(0.380 \pm 0.03 \mu \mathrm{g} \mathrm{L}^{-1}\right)$. Cadmium was below the limit of detection in this material, and it was not determinate. An addition/recovery test was carried out in one PFW sample for both metals. Recoveries between 91 to $107 \%$ were obtained.

The analytical method was applied in the determination of $\mathrm{Cu}$ and $\mathrm{Cd}$ in ten petroleum formation-water samples and results are presented in Table 5. Copper concentrations ranged from $<0.030$ to $2.29 \mu \mathrm{g} \mathrm{L}^{-1}$, and cadmium ranged from $<0.12$ to $2.14 \mu \mathrm{g} \mathrm{L}^{-1}$. The concentrations of copper and cadmium found in the samples are in the range of concentration below the limit established by CONAMA 
Table 5. Results of the determination of $\mathrm{Cu}$ and $\mathrm{Cd}$ in produced-formation waters samples applying the developed CPE GF AAS method

\begin{tabular}{lcc}
\hline Sample & $\mathrm{Cu} /\left(\mu \mathrm{g} \mathrm{L}^{-1}\right)$ & $\mathrm{Cd} /\left(\mu \mathrm{g} \mathrm{L}^{-1}\right)$ \\
\hline 1 & $1.96 \pm 0.05$ & $2.1 \pm 0.2$ \\
2 & $1.8 \pm 0.1$ & $1.41 \pm 0.01$ \\
3 & $1.71 \pm 0.08$ & $1.4 \pm 0.2$ \\
4 & $1.5 \pm 0.3$ & $<0.12$ \\
5 & $<0.030$ & $<0.12$ \\
6 & $1.5 \pm 0.4$ & $<0.12$ \\
7 & $1.15 \pm 0.02$ & $1.41 \pm 0.04$ \\
8 & $1.07 \pm 0.01$ & $1.32 \pm 0.02$ \\
9 & $2.3 \pm 0.1$ & $<0.12$ \\
10 & $<0.030$ & $1.3 \pm 0.2$ \\
\hline
\end{tabular}

Resolution No. 357, of March 17, 2005, ${ }^{20}$ which calls for a maximum value of $5 \mu \mathrm{g} \mathrm{L}^{-1}$ of copper and cadmium in seawater where oil extraction takes place.

\section{Conclusions}

The proposed cloud-point extraction for cadmium and copper and the determination by graphite furnace atomic absorption spectrometry of trace amounts of these metals from matrices with high saline content such as produced-formation water proved to be an efficient method. The optimization studies allied with the use of constrained mixture design have to aid in finding the experimental conditions to extract efficiently these metals. The concentrations of copper and cadmium found in the samples were in the range of concentration below the limits established by the Brazilian environmental agency.

\section{Acknowledgments}

Authors acknowledge the financial support of the Fundação de Amparo à Pesquisa do Estado da Bahia (FAPESB), Coordenação de Aperfeiçoamento de Pessoal de Nível Superior - Brasil (CAPES) - Finance Code 001, Conselho Nacional de Desenvolvimento Científico e Tecnológico (CNPq, No. 304582/2018-2), Financiadora de Estudos e Projetos (FINEP) and Programa de Formação de Recursos Humanos da ANP PRH/ANP/MCT.

\section{References}

1. Oliveira, E. P.; Santelli, R. E.; Cassella, R. J.; Microchem. J. 2008, 89, 116.
2. Oliveira, E. P.; Yang, L.; Sturgeon, R. E.; Santelli, R. E.; Bezerra, M. A.; Willie, S. N.; J. Anal. At. Spectrom. 2011, 26, 578.

3. Khan, A.; Khan, S. K. M. A.; Ullah, M. A. H.; Rehman, J. N. I. U.; Int. J. Environ. Sci. Technol. 2019, 16, 2295.

4. Grenni, P.; Barra, A.; Mariani, L.; Cardoni, M.; Riccucci, C.; Elhaes, H.; Ibrahim, M. A.; Microchem. J. 2019, 147, 1010.

5. Aswathi, M.; Mathai, S.; Joseph, S. C.; Biju, V. M.; Sep. Sci. Technol. 2017, 52, 2540.

6. Naeemullah; Kazi, T. G.; Shah, F.; Afridi, H. I.; Khan, S.; Arian, S. S.; Brahman, K. D.; J. Anal. Methods Chem. 2012, 713862.

7. Ferreira, A. C.; Costa, A. C. S.; Korn, M. G. A.; Microchem. J. 2004, 78, 77.

8. Xie, M.; Sun, Y.; Feng, J.; Gao, Y.; Zhu, L.; Aquat. Toxicol. 2019, 210, 106.

9. Miranda-Andrades, J. R.; Khan, S.; Toloza, C. A. T.; Maciel, R. M.; Escalfoni Jr., R.; Tristão, M. L. B.; Aucelio, R. Q.; Microchem. J. 2019, 146, 1072.

10. Menezes, J.; Sousa, D.; Tadeu, M.; Cassella, R. J.; Microchem. J. 2018, 138, 92.

11. Zhu, X.; Hu, B.; Jiang, Z.; Li, M.; Water Res. 2005, 39, 589.

12. Costa, B. E. D. S.; Coelho, N. M. M.; Coelho, L. M.; Food Chem. 2015, 178, 89.

13. Naeemullah; Kazi, T. G.; Shah, F.; Afridi, H. I.; Baig, J. A.; Soomro, A. S.; J. AOAC Int. 2013, 96, 447.

14. Silva, S. G.; Oliveira, P. V.; Rocha, F. R. P.; J. Braz. Chem. Soc. 2010, 21, 234.

15. Bezerra, M. A.; Ferreira, S. L. C.; Extração em Ponto Nuvem: Princípios e Aplicações em Química Analítica; UESB: Vitoria da Conquista, Brazil, 2006.

16. Depoi, F. S.; Pozebon, D.; J. Braz. Chem. Soc. 2012, 23, 2211.

17. Baghban, N.; Shabani, A. M. H.; Dadfarnia, S.; Jafari, A. A.; J. Braz. Chem. Soc. 2009, $20,832$.

18. Garcia, S.; Gerondi, F.; Paixão, T. R. L. C.; Arruda, M. A. Z.; Gaubeur, I.; J. Braz. Chem. Soc. 2015, 26, 490.

19. Afkhami, A.; Madrakian, T.; Siampour, H.; J. Braz. Chem. Soc. 2006, 17, 797.

20. Resolução CONAMA No. 357, de 17 de março de 2005, Dispõe sobre a Classificação dos Corpos de Água e Diretrizes Ambientais para o seu Enquadramento, bem como Estabelece as Condições e Padrões de Lançamento de Efluentes, e Dá outras Providências; Diário Oficial da União (DOU), Brasília, No. 053, de 18/03/2005, p. 58-63. Available at http://www2. mma.gov.br/port/conama/legiabre.cfm?codlegi $=459$ accessed in January 2020.
Submitted: September 20, 2019

Published online: January 14, 2020 